\title{
Environmental analysis of various systems for the cogeneration of biogas produced by an urban wastewater treatment plant (UWTP). (III).
}

\author{
J.J. Coble ${ }^{1}$ and A. Contreras ${ }^{2 *}$ \\ ${ }^{1}$ Department of Industrial Engineering. Nebrija Universidad. Madrid , Spain \\ ${ }^{2}$ Department of Chemistry. ETSII. UNED. Madrid. Spain. \\ * Corresponding author. Tel: 3491 3986496, Fax: 3491 3986043. Email: acontreras@ind.uned.es
}

\begin{abstract}
To complete the study on harnessing the biogas produced by a UWTP as an energy source, using cogeneration with motor-generators and phosphoric acid fuel cells, in this paper we present the results of the environmental study. This completes the study made of both systems, enabling us to conclude which of the two methods is best in terms of obtaining the largest amount of energy, at the lowest cost, and with minimum impact on the environment.
\end{abstract}

For the environmental analysis we compared, amongst other parameters, the contaminating gas emissions produced by each cogeneration device, and assessed the financial cost of the environmental damage caused by these emissions. We also bore in mind the emission levels created by the emissions from each system, both immediately around the plant and in the surrounding areas affected by prevailing wind directions. Finally, we compared the noise levels of the two devices and determined the financial cost of applying corrective acoustic insulation where necessary.

The overall study of both systems has made it clear that to evaluate them correctly, it is necessary to internalize all the costs that are currently externalized. This is the only way to find the true cost of each system.

Keywords: Cogeneration, UWTP, Motor-generators, Phosphoric acid fuel cell, Environmental analysis, Emissions.

\section{Introduction}

In the first part of this study [1], it was found that both systems showed substantial differences in terms of their energetic, exergetic and thermo-economic performance. The irreversible factors of both systems are shared out among their components in different ways but, overall, there are fewer of these factors in the phosphoric acid fuel cell system. However, if we take the energy analysis alone into account, the total year-on-year costs are lower for the motorgeneration system, and this is the option that would normally be chosen.

In this second part of the study it becomes apparent that if we add up the costs of both thermoeconomic analysis and environmental analysis, i.e.: by internalizing all the costs of both systems, cogeneration with phosphoric acid fuel cells is an investment that can be eventually be recovered. However, this is not the case with cogeneration using motor-generators.

\section{Methodology}

The environmental analysis compares the two cogeneration systems on the basis of the following features:

Emission levels of atmospheric pollutants and greenhouse gases, along with their financial cost.

Emission levels in surrounding and sensitive areas, and their environmental impact.

Noise levels and their financial cost.

Once the environmental impacts have been assessed, they must be assigned a financial cost and this must be internalized with the rest of the system's costs. The cost of externalities has 
been evaluated by various international organizations. Two studies are fundamental if we wish to make an assessment of the costs of the externalities of the systems studied in this paper: one is European [2], and was subsequently developed in [4, 5], and the other is American [3]. The American model basically uses resolution algorithms, which are in turn based on the same concept: the cost of environmental damage attributable to each unit of mass or volume of pollutant.

However, we decided to use the European model [2, 4, 5], because its conclusions are better suited to the environment in which this study took place, but mainly because it is a more conservative model insofar as the numeric values that are obtained are always higher than the real ones. This provides us with a safety margin that is always appreciated by technicians.

In order to assign costs to the externalities, it is first necessary to decide which of these should be taken into account. In this study, we considered those that are due to the emission and noise levels produced by the systems.

We also calculated the levels of emission of chemical pollutants (gaseous compounds and particles), depending on the location's various climatic conditions, so as to compare the final environmental impact of the emissions from each system. No cost was assigned to them, however, because taking into account the costs of the irreversible energy factors and the emissions alone was sufficient proof of the financial difference between the two systems.

From the results obtained in the studies mentioned [2, 4, 5], the emission costs for various scenarios can be inferred, as shown in Table 1. These differ depending on the financial valuation of the emissions.

Table 1. Costs of the emissions of pollutants in various scenarios (euros/ton)

\begin{tabular}{llll}
\hline $\begin{array}{l}\text { ATMOSPHERIC } \\
\text { POLLUTANT }\end{array}$ & $\begin{array}{l}\text { LOW } \\
\text { LEVEL }(€ / \mathrm{t})\end{array}$ & $\begin{array}{l}\text { MEDIUM } \\
\text { LEVEL }(€ / \mathrm{t})\end{array}$ & $\begin{array}{l}\text { HIGH } \\
(€ / \mathrm{t})\end{array}$ \\
\hline $\mathrm{CO}_{2}$ & 9.90 & 26.40 & 41.60 \\
\hline $\mathrm{CO}$ & 506.23 & $1,055.87$ & $2,494.26$ \\
\hline $\mathrm{SO}_{2}$ & $1,635.98$ & $1,869.77$ & $4,933.99$ \\
\hline $\mathrm{NO}_{\mathrm{X}}$ & $1,049.27$ & $7,919.03$ & $10,030.77$ \\
\hline $\mathrm{PM}$ & $3,128.55$ & $4,839.41$ & $13,616.33$ \\
\hline $\mathrm{VOC}$ & $1,113.06$ & $5,265.79$ & $6,489.20$ \\
\hline
\end{tabular}

In this study, we have chosen the medium-level costs of emissions shown in Table 1, as we consider them to be the most representative. The nomenclature used for the financial costs that have been developed and used in this study (set-up and operation, energy inefficiency, emissons) is as follows:

$\mathbf{C}_{1}$ (€/year): Set-up and operating costs during the first year. In subsequent years only operating costs will be taken into account.

$\mathbf{C}_{2}$ (€/year): Costs of energy inefficiency derived from the thermo-economic analysis.

$\mathbf{C}_{3}$ (€/year): Costs of noise emissions and atmospheric pollutants. 


\section{Results}

The results of the emission and noise levels for each of the two cogeneration systems studied are shown below.

\subsection{Level of emissions from the cogeneration system using motor-generators}

The combustion reactions of the motor-generators were modelled on the basis of the excess of air $n=1.5$ that was considered. Using the formula created with the EES programme [10], we obtained the motor-generator emission results shown in Table 2, and these were compared with those of the phosphoric acid fuel cells.

Table 2. Comparison of gases emitted by biogas cogeneration by motor-generators and in fuel cells, in grams per second.

\begin{tabular}{|c|c|c|c|c|c|c|c|}
\hline \multicolumn{2}{|c|}{$\begin{array}{l}\text { NOx } \\
\text { EMISSIONS(g/s) }\end{array}$} & \multicolumn{2}{|c|}{$\begin{array}{l}\mathrm{SO}_{2} \\
\text { EMISSIONS } \\
(\mathrm{g} / \mathrm{s}) \\
\end{array}$} & \multicolumn{2}{|c|}{$\begin{array}{l}\mathrm{CO}_{2} \\
\text { EMISSIONS(g/s) }\end{array}$} & \multicolumn{2}{|c|}{$\begin{array}{l}\text { CO } \\
\text { EMISSIONS(g/s) }\end{array}$} \\
\hline $\begin{array}{l}\text { Motor- } \\
\text { generator }\end{array}$ & PAFC & $\begin{array}{l}\text { Motor- } \\
\text { generator }\end{array}$ & PAFC & $\begin{array}{l}\text { Motor- } \\
\text { generator }\end{array}$ & PAFC & $\begin{array}{l}\text { Motor- } \\
\text { generator }\end{array}$ & PAFC \\
\hline 4.51364 & 0.00214 & 0.03482 & 0 & 731.13516 & 244.66 & 24.48778 & 0.00497 \\
\hline
\end{tabular}

\subsection{Level of emissions from the cogeneration system using phosphoric acid fuel cells.}

Using the available data [7, 8], the emissions from fuel cells were modelled on the basis of the level of working power. With the formula created by the EES programme [6], we obtained the emission results that are also shown in Table 2, above.

The $\mathrm{SO}_{2}$ emissions for fuel cells are negligeable and have not been taken into account. To make a financial assessment of the emissions, we used the average value of emission costs shown in Table 1. Using these values as a reference, we were able to determine the emission costs of all the compounds mentioned in the study.

Table 3 shows the costs resulting from the emissions from each cogeneration system and compound, whereas Table 4 shows the sum of all the costs for each case.

Table 3. Financial comparison of emission costs for $\mathrm{NOx}$, SO2, $\mathrm{CO} 2$ and $\mathrm{CO}$ emissions, from both cogeneration systems ( $€ /$ year).

\begin{tabular}{|c|c|c|c|c|c|c|c|}
\hline $\begin{array}{l}\text { COST OF } \\
\text { EMISSION } \\
(€ / \text { year })\end{array}$ & NOx & $\begin{array}{l}\text { COST OF } \\
\text { EMISSIO } \\
\text { (€/year) }\end{array}$ & ${ }_{\mathrm{JS}} \mathrm{SO}_{2}$ & $\begin{array}{l}\text { COST OH } \\
\text { EMISSION }\end{array}$ & $\mathrm{S}$ (€/year) & $\begin{array}{l}\text { COST OF } \\
\text { EMISSIONS } \\
(€ / \text { year })\end{array}$ & $\mathrm{CO}$ \\
\hline $\begin{array}{l}\text { Motor- } \\
\text { generator }\end{array}$ & PAFC & $\begin{array}{l}\text { Motor- } \\
\text { generator }\end{array}$ & PAFC & $\begin{array}{l}\text { Motor- } \\
\text { generator }\end{array}$ & PAFC & $\begin{array}{l}\text { Motor- } \\
\text { generator }\end{array}$ & PAFC \\
\hline $539,285.94$ & 256.02 & 981.63 & 0.00 & $291,219.64$ & $97,452.22$ & $390,071.85$ & 79.25 \\
\hline
\end{tabular}


Table 4. Financial comparison of total costs $\left(\mathrm{C}_{3}\right)$ from emissions of $\mathrm{NO}_{x}, \mathrm{SO}_{2}, \mathrm{CO}_{2}$ and $\mathrm{CO}$, from both cogeneration systems ( $€ /$ year).

\begin{tabular}{lc}
\hline TOTAL COST OF & $\mathrm{C}_{3}$ \\
EMISSIONS ( $€ /$ year) & \\
\hline $\begin{array}{l}\text { Motor- } \\
\text { generator }\end{array}$ & PAFC \\
\hline $1,221,559.06$ & $97,787.49$ \\
\hline
\end{tabular}

As can be seen from Table 4, the total costs of atmospheric emissions from the motorgenerators are 5.64 times higher than those of fuel cells.

As shown by the figures in Table 1, the financial cost of emissions is considered to be included in the cost of emissions shown in the previous section. However, in this study, we took into account the dispersion of pollutants according to the atmospheric conditions of the location, and emission maps were subsequently made. This was because the way in which emissions are financially assessed - which currently includes the effects of immissions - needs to be improved. It should be requisite for a device's emission levels to be used simultaneously with emission maps calculated for the device's various weather scenarios. This study will make it possible to achieve a more accurate financial assessment of the environmental impact.

Level of emissions from the cogeneration system using motor-generators.

We show below a summary of the results of the emission level calculations for each pollutant and each cogeneration system. We used the DISPER 3.0 programme [9] and an Excel spreadsheet [10], introducing the emission data calculated in Table 2 into the programme's user interface (except for the $\mathrm{CO}_{2}$ figures). By also introducing the weather and other relevant location data, we obtained the $\mathrm{CO}$ results shown below, in Figure 1, as well as each kind of atmospheric stability for the profile on the $\mathrm{XZ}$ plane of the central line of the plume (X axis).

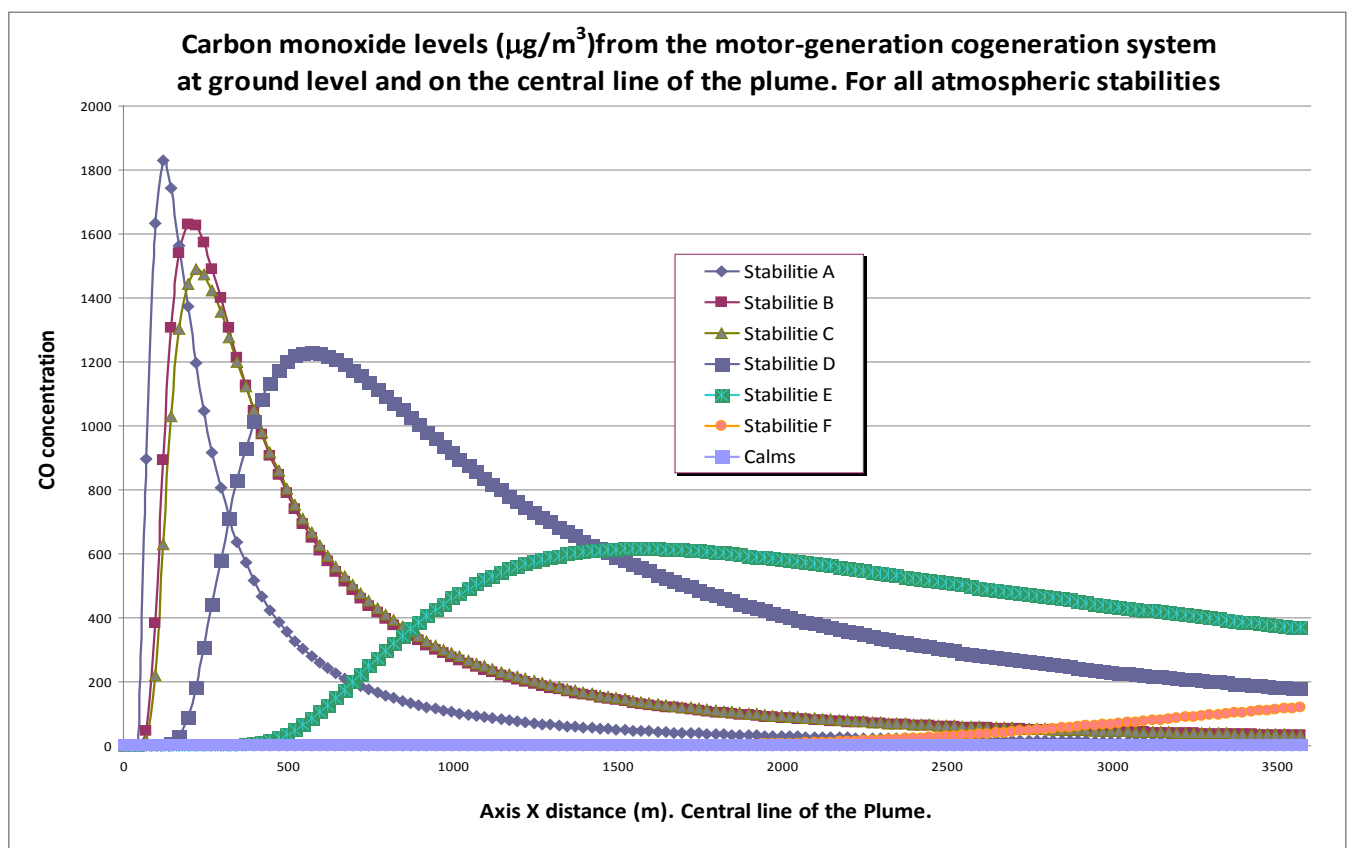

Figure 1. Carbon monoxide levels from the motor-generation cogeneration system at ground level and on the central line of the plume. For all atmospheric stabilities. 
As can be seen in Figure 1, the maximum concentration of carbon monoxide immission for the most unfavourable atmospheric stability is:

$1800 \mu \mathrm{g} / \mathrm{m}^{3}=1,8 \mathrm{mg} / \mathrm{m}^{3}<6 \mathrm{mg} / \mathrm{m}^{3}$ (legal limit).

This in no case exceeds the legal limits in force since January 1, 2005 [11].

Level of emissions from the cogeneration system using phosphoric acid fuel cells.

Carbon monoxide is mainly produced in the fuel cell during the process of reforming the biogas vapour to obtain hydrogen. This carbon monoxide has to be removed from the fuel flow into the cell to avoid poisoning the catalyst.

This CO has to be removed from the reformed gas flowing into the fuel cell, because carbon monoxide concentrations as low as $1 \%$ in the input flow of these cells can poison the platinum catalyst. Although the operating temperature of the cells is between $150-200^{\circ} \mathrm{C}$, the effects of catalyst poisoning can be detected at concentrations of 10,000ppm of $\mathrm{CO}$ in the input flow. The main effect of such poisoning is either an increase in the input flow required to produce the same power, or a drop in the power output [12].

The results of the levels of carbon monoxide emission calculated in this case provide a maximum concentration figure for the most unfavourable atmospheric stability of:

$2.5 \mu \mathrm{g} / \mathrm{m}^{3}=0.0025 \mathrm{mg} / \mathrm{m}^{3}<<<6 \mathrm{mg} / \mathrm{m}^{3}$ (legal limit)

If the above figure is compared to the concentration level of $\mathrm{CO}$ emissions from motorgenerator emissions for the least favourable atmospheric stability, it can be seen that emissions from the motor-generators are around 720 times higher than those of the set of fuel cells.

Similar results were obtained for the rest of the polluting gases considered in this paper. As for emission and emission levels, the motor-generator cogeneration system is at a clear disadvantage when compared to the phosphoric acid fuel cell system.

The noise level of the motor-generator cogeneration system.

For the calculations in this section, we used the data provided by the manufacturers - which, in both cases, dealt with emissions into the indoor (rather than outdoor) atmosphere of 95 $\mathrm{dBA}$ for motor-generators, and $60 \mathrm{dBA}$ for fuel cells $[13,14]$, as well as current regulations.

To check that the noise level limits set by the current legislation were not exceeded, we used the CUSTIC 1.0 application, by Canarina Software Ambiental [15], to calculate the noise emission levels. These were viewed on isophonic layout maps, for both the installation using motor-generators and the one using phosphoric acid fuel cells.

In the case of the motor-generators, the noise levels calculated in the simulation would exceed the 60dBA day-time limit, beyond the walls of the motor-generation building, unless appropriate corrective measures were put in place. In order to comply with the law, it would be necessary to take corrective measures amounting to 43,500 Euros. With fuel cells, no corrective measures are required 


\section{Conclusions}

By considering environmental effects in our analysis of the two cogeneration systems, we were able to reach the following conclusions.

The most important aspect of this second part of the study is that the environmental cost of the phosphoric acid fuel cell cogeneration system has been valued at 97,787.487 €/year, whereas that of the motor-generator cogeneration system was $1,221,559.061 € /$ year. As you can see, the latter is far higher than the phosphoric acid fuel cell system.

Furthermore, in the case of motor-generators, acoustic insulation would need to be provided for the building in which they are installed, so as to comply with current legislation on noise emission levels. In the case of the fuel cell cogeneration system, however, no corrective measures are needed to comply with these regulations.

\section{References}

[1] J.J. Coble, and A. Contreras. Energetic, Exergetic, Thermoeconomic and Environmental Analysis of Various Systems for the Cogeneration of Biogas Produced by an UWTP (1). 18 World Hydrogen Energy Conference, 16-21 May 2010, Essen, Germany.

[2] Scheleisner and Nielsen, (1997). ExternE National Implementation Project (CEC, 1995)

[3] R. D. Rowe et al.,. The New York Electricity Externality Study. Oceana Publications, New York. 1995.

[4] Carlson Annelie, Energy system analysis of the inclusion of monetary values of environmental damage, Biomass and Bioenergy (2002), 22,3,177-177

[5] European Commission ExternE- Externalities of Energy, EUR 16520 EN-EUR 16525 EN, Directorate-General XII, Office for Official Publications of the European Communities, Luxembourg, 1995.

[6] EES (Engineering Equation Solver). F-Chart Software. www.fchart.com.

[7] Greenhouse Gas Technology Center Southern Research Institute. EPA \& New York State Energy Research and Development Authority (2004). "Environmental Technology Verification Report: Electric Power and Heat Generation Using UTC Fuel Cells` PC25C Power Plant and Anaerobic Digester Gas”.

[8] Ott G. Sanger D. Tooze D. Hydrogen Fuel Cells: A Solution for Utilizing Waste Methane at Columbia Boulevard Wastewater Treatment Plant. Final Technical Report. Climate Change Fuel Cell Program (2000). City of Portland. Oregon

[9] Canarina environmental software, program DISPER 3.0 advanced version. www.canarina.com

[10] Microsoft Excel software. http://office.microsoft.com

[11]BOE num. 260, 30/10/2002. Ministry of the Presidency. Royal Decree 1073/2002, of 18 October, on the evaluation and management of air quality in relation to sulphur dioxide, nitrogen dioxide, nitrogen oxide, particles, lead, benzene and carbon monoxide.

[12] Song Rak-Hyung, Shin D. R., Influence of CO concentration and reactant gas pressure on cell performance in PAFC, International Journal of Hydrogen Energy 26 (2001) 12591262.

[13] PureCellTM Model 200 power solution. www.utcpower.com. 
[14]J. Larminie and A. Dicks. Fuel Cell Systems Explained (Second Edition). J. Wiley and Sons.

[15]Canarina environmental software, program CUSTIC 1.0 advanced version. www.canarina.com. 